\title{
Örgütsel Zeka Algısı ve Ortak Değişkenlerin Etkisi: ANCOVA Analizi ile İncelenmesi
}

\section{Organizational Intelligence Perception and Effects of Covariates: Investigation with ANCOVA Analysis}

\author{
Nilay NEYişçi*
}

\author{
Nihan POTAS
}

\section{Şefika Şule ERÇETiN ${ }^{* \star \star}$}

\begin{abstract}
Toplumsal Mesaj.
Çalışmamızın amacı örgütsel zekâ ve örgütsel zekânın eylemsel boyutlarının düzeylerini ortaya koymak ve bu görüşlerin ortak değişlerin etkisi ile farklılaşıp farklılaşmadığını incelemektir. Araştırma sonuçlarına göre öğretmen ve yöneticilerin okullarının örgütsel zeka düzeyine ilişkin algıları orta düzeydedir.
\end{abstract} açısından incelendiğinde, lisans ve yüksek lisans mezunu katılımcıların, ön lisans mezunlarına göre örgütün işleyişine ilişkin kuralların gerektiğinde değiştirilebilir nitelikte olması ve bürokratik işlemlerin örgütsel hızı azaltmayacak düzeyde yapılması konularında ilkokulun daha etkili davrandığını düşündükleri belirlenmiştir.

Anahtar Kelimeler: Zeka, Örgütsel zeka, Örgütsel zeka boyutları, İlkokul.

\begin{abstract}
The aim of this study is to determine the level of the organizational intelligence and its subdimensions according to the opinions of teachers and administrators who work in the selected primary school and whether these opinons differ according to demographic variables such as age, gender, seniority, school working year and education level. The study group consists of 48 people working in a primary school in Çankaya distict Ankara province in the academic year 2018-2019. The data obtained with "Multidimensional Organizational Intelligence Scale" was analyzed with quantitative methods by using descriptive statistics, t-test and variance analysis as Anova and Ancova. According to the results of the research, teachers' and administrators' perceptions about the organizational intelligence level of their schools are at medium level and they have a high perception in being rapid in action and reaction dimension. When the effect of age, seniority and working year variables are determined, bachelor's and master's degree graduates believe that their school is more effective when the rules concerning the functioning of the organization are subject to change if necessary and bureaucratic procedures are done at a level that does not reduce the organizational speed.
\end{abstract}

Keywords: Intelligence, Organizational intelligence, Organizational intelligence dimensions, Primary school.

\section{Public Interest Statement.}

The aim of our study is to reveal the levels of the organizational dimensions of organizational intelligence and organizational intelligence and to examine whether these views differ with the effect of common changes. According to the results of the research, the perception of teachers and administrators about the organizational intelligence level of their schools is moderate.

\footnotetext{
* Orcid ID: https://orcid.org/0000-0002-9360-5337, Araş. Gör. Dr., Hacettepe Üniversitesi, Eğitim Fakültesi, Eğitim Bilimleri Bölümü, nilbasar@hacettepe.edu.tr

** Orcid ID: https://orcid.org/0000-0002-0393-3135, Dr. Öğr. Üyesi, Ankara Hacı Bayram Veli Üniversitesi, İktisadi ve İdari Bilimler Fakültesi, Sağlık Yönetimi Bölümü, nihan_potas@hotmail.com

*** Orcid ID: http://orcid.org/0000-0002-7686-4863, Prof. Dr., Hacettepe Üniversitesi, Eğitim Fakültesi, Eğitim Bilimleri Bölümü, sefikasule@gmail.com
} 


\section{GiRiş}

Günümüz örgütleri, sürekli değişen koşullar ve durumlara uyum sağlama çabaları ile diğer organizmalar gibi çevre ile yoğun bir etkileşim halindedirler. Giderek karmaşıklaşan yapılar ve belirsizlik içerisinde hayatta kalma çabaları, örgütlerin öğrenme ve zeka potansiyellerinin bir belirtisi olarak karşımıza çıkmaktadır. Bu bağlamda örgütsel amaçlara ulaşmak için, değişime uyum sağlama ve bununla birlikte bilgiye ulaşma yeteneklerini geliştirerek, örgütsel bir öğrenme sürecini işe koştukları söylenebilir.

Örgüt üyelerinin bireysel öğrenmelerinin, örgütün amaçlarına ulaşmasına katkı sağladığı yadsınamaz. Ancak örgütün öğrenmesinin bu durumun ötesinde, kendi bilişsel sistemi ve hafızaları ile gerçekleştiği ifade edilebilir (Yıldırım, 2010). Örgüt üyelerinin veya liderlerin zaman içerisinde değişmesinden bağımsız olarak kendi bilişsel süreçlerini, kültür ve normlarını ortaklaşa sürdürdükleri görülebilmektedir. Bu sayede kendilerini yenileme ve uyum sağlama yeteneklerini de geliştirebilmektedirler. Bu durumda intiyaç duyulan bilgiyi üretme, elde etme ve kullanabilme yeteneğine sahip olmak, örgütsel öğrenmenin gerçekleşmesinde temel bir yeterlik olarak sözedilen örgütsel zekanın bir göstergesidir (Kalkan, 2006; Yıldırım, 2010). Zeki örgütlerin bilgiyi elde etme ve üretmelerinin yanı sıra, çevresi ile etkileşim kurarak kendini yeniden şekillendirmesi ve öğrenilen bilgileri paylaşarak çevresini değiştirmesi beklenmektedir (Schwaninger, 2003; Yıldırım, 2010; Stenvall ve Virtanen, 2017).

Öğrenme, varlıkların yaşamlarını sürdürebilmeleri için önemli bir faaliyettir. Bireyin yeni bilgiler yoluyla davranış değişikliği kazanma sürecidir. Çağdaş yönetim paradigmasında organizma olarak tanımlanan örgütlerin, bilgiyi üretmek ve kullanabilmek için çevresel koşullarla uyumlu hale gelmeleri ve değişimleri hissetmeleri önemlidir. Bunu gerçekleştirebilmek için kendi hafızaları ve bilgi üretim süreçlerini işe koşarak öğrenmeyi gerçekleştirmeleri beklenmektedir. Günümüzdeki örgütlerin öğrenmeleri değerlendirildiğinde, değişme, yaratııılık, ilerleme ve inovasyon kavramları ile ilişkilendirilerek farklı becerileri gerçekleştirmeleri beklenmektedir (Yazıcı, 2001).

Örgütsel öğrenme, ortak bir amaç için birlikte hareket eden üyelerin rollerini anlamlandırmaları ve daha verimli çalışabilmelerini sağlayan yeteneklerin geliştirilmesi sürecini ifade eder (Barutçugil, 2002). Bilgiyi aktarmak, üretmek ve uygulamak için örgütlerin davranış geliştirme yetenekleri, örgütsel öğrenmeleri ile yakından ilgilidir. Yazıcı'ya göre (2001) örgütsel öğrenme, tüm üyelerin katılımı ile oluşan ortak davranış, değer ve normların paylaşılma sürecidir. Öğrenen örgütlerin yaşamlarını sürdürmeleri için kendi geleceklerini yaratmaları, üyelerin ortak amaçlar doğrultusunda gösterdikleri çabaları ile yakından ilgilidir. Dinamik bir bilgi üretim ve aktarım sürecini ifade eden örgütsel öğrenme, örgütün performansını değerlendirme ve geliştirme çabalarını içerir. Bu devinimsel, birey ve grup temeline dayalı performans geliştirme süreci, örgütsel hafızanın oluşmasında önemli bir role sahiptir (Huber, 1991, Walsh ve Ungson, 1991; Crossan, Lane ve White, 1999). Öğrenme ile yenilik, değişim ve güncellik sağlayan örgütler, amaçlara ulaşmak ve uygulamaları hayata geçirmek konusunda daha başarııdırlar (Şimşek ve Çelik, 2011). Bilgiyi işleme, yenilik, şeffaflık ve yaratıcılık gibi yeterliliklerin ön plana çıktığı örgütsel öğrenme sürecinde örgütsel zeka olumlu bir role sahiptir (Mills ve Friesen, 1992). Örgütsel öğrenme sürecinde bilgiyi üretme, işleme ve bilgiye uyum sağlama aşamaları birikimli olarak ilerlemekte ve bu süreç örgütsel hafızanın ortaya çıkmasını sağlamaktadır. Bu aşamalarda kullanılan örgütsel kapasite, örgütün zekasını ifade etmekte ve örgütsel öğrenme için kilit bir kavram olmaktadır.

\section{1 Örgütsel Zekâ}

Örgütlerin, çağın gereksinimleri ile uyum gösterme ve çoğu zaman belirsizlik ile baş edebilme becerileri yaşamlarını sürdürebilmeleri konusunda karar verici yetenekler olarak öne çıkmaktadır. Örgütsel zeka ile ilişkilendirilen bu yetenekler, örgütlerde bilgi kullanımı ile yakından ilgilidir. Bu sebeple, bilgi üretmek ve bilgiye sahip olabilmek örgütler için yaşamsal özelliklerdendir (Halal, 1998; Albrecht, 2002; Erçetin, 2001, 2004a, 2004b). Zeka soyut bir kavram olarak farklı disiplinlerde ele alınarak pek çok farklı tanımlamalar yapıımıştır. Zeka, öğrenme yeteneği, çevreye uyum sağlama kabiliyeti, problem çözme yeteneği veya bilgi ve becerileri yeni durumlara uyarlama yeteneği olarak 
farklı alanlarda tanımlanmıştır (Feuerstein, 1990; Erçetin ve Demirbulak, 2002; Bümen, 2005; Gardner, 2006; Keleş ve Özkan, 2010; Istudor, Ursacescu, Sendroiu ve Radu, 2016). Algılarımızı kullanarak getirdiğimiz bilgilerle ulaştığımız yargılar ve genellemeleri sistemli bir şekilde işe koşabilme süreci olarak da tanımlanan zeka, bilişsel bir işlevi ifade etmektedir (Çakır, 2008).

Öğrenme, adaptasyon, değişim ve büyüme gibi kavramlardan hareketle örgütlerin de benzer süreçlerden geçtiği, ancak örgütün zekasının bireylerin toplam zekasından daha farklı işlediği söylenebilir (Erçetin, Potas, Kisa ve Açikalin, 2012). Örgütlerin amaçlara ulaşmak için davranış değiştirmeleri, bilgiyi yönetme becerileri ve bu anlamda işe koşulan yeteneklerin tümü örgütsel zeka ile ilişkilendirilmektedir (Minch,1990). Örgütsel zeka kapsamında, örgütlerin karmaşık olguları anlamlandırma, çevreyi anlayabilme ve uyum sağlama, hedeflere yönelik bilgi üretme ve paylaşma, deneyimlerinden öğrenme becerilerine sahip olmaları beklenmektedir (Veryard, 2016).

Çok boyutlu karmaşık bir yapıyı tarif eden tanımlarda zeki örgütlerin stratejik vizyon geliştirme yetenekleri, değişim istekleri ve uyum yeteneklerinin yanı sıra, ortak başarı güdüleri, bilgi alışverişi ve ortak enerjilerine de vurgu yapılmaktadır (Albrecht, 2002; Çakır, 2008). Örgütsel zekâ, üyelerin zekâlarıyla, örgüte ait teknik yapıların etkileşim ve uyumunu ifade etmektedir. Etkileşim boyutunda, örgütteki farklı yapıların ilişkileri düşünülebilir. Örgütsel zekâ özellikle örgütsel sorunların çözümünde bilginin yapılanmasını, sentezlenmesini ve amaç odaklı ele alınmasını gerektirmektedir (Çakır, 2008). Örgütsel zekanın bireylerin toplam zekası ile oluştuğunu vurgulayan Glynn (1996), zeka uygulama ve ölçümleri ile birleştirme, geçiş ve yayılma modelinden oluşan bir örgütsel zeka modeli tanımlamıştır. Birleştirme modelinde üyelerin zekalarının toplamının örgütsel zekayı meydana getirdiği, geçiş modelinde üyelerin zekalarının dönüşüm ve kodlanması ile örgüt zekasının oluştuğu ve yayılma modelinde ise zekanın örgüt içerisindeki düzenli yapılar içinde geliştiği ifade edilmektedir. Örgütsel zekâ, örgütün hayatta kalmasını sağlayan yeteneklerin tamamı ve kullanımı olarak ele alınmaktadır (Erçetin, 2001; Albrecht, 2002). Bu yetenekler Erçetin ve diğerleri (2004b) tarafından Eylem ve tepkide çabukluk, Değişen durumlara uyarlanabilme, İşleyişte esnek ve rahat olabilme, Sezebilme ve öngörülü olabilme, Açık fikirli olabilme, Hayal gücünü kullanabilme ve Yenilenebilme olarak sıralanmaktadır.

\subsection{Zeki Örgütler Olarak Okullar}

Sistem yaklaşımları temelinde değerlendirildiğinde eğitim, farklı yapılardan oluşan pek çok alt sistemden oluşmaktadır. Yoğun bir değişim ve gelişim süreci içerisinde, yüksek beklentiler ile şekillenen eğitim sisteminin temel yapı taşlarından biri okuldur ve tüm değişim ve gelişim sürecinin uygulama basamağını ifade etmektedir. Bu bağlamda eğitim sisteminin temelini oluşturan okulların örgütsel zekâlarını kullanmaları ve geliştirmeleri beklenmektedir (Erçetin ve Demirbulak, 2002).

McGilchrist (2009) başarılı okulların öğrenme-öğretme ve gelişim girişimleri için dokuz zeka türünü işe koştuklarını ileri sürmektedir. Bu zeka alanları şu şekilde tanımlanmaktadır:

Bağlamsal zekâ. Okulun sahip olduğu kapasite ile kendisini daha geniş bir toplumun parçası olarak görebilmesidir. Bu kapasite okulun toplum ile uyumunu mümkün kılar ve aynı zamanda olumlu ve olumsuz yönlerine ilişkin dönüt alabilir. Aynı zamanda kendi kendini örgütleyen kapasiteyle tanımlanır.

Stratejik zekô. Okulun tüm üyelerinin ortak amaçlar etrafında toplanmasını içerir. Amaçların netliği ve standartlaşma ile okul etkililiğin artmasını kapsamaktadır. Bu zekânın türü kapsamında, okulun gelişim gereksinimlerini planlayarak uygulamaya geçirmek için geleceği kestirebilme yeteneğinin olduğunu gösterir. Bu amaçla stratejik planlarında, gelişme için uzun dönem hedefler, yeni bilgiler ile düzenli tekrar gözden geçirme ve tekrarlama ile gerçekleştirilir.

Akademik zekô. Üst düzey akademik bilgi değerleri ile tanımlanan bu zeka türünde değer, etkili öğrenme ve öğretme nitelikleri ile yüksek başarı beklentileri gibi kavramları içerir. Öğrencilerinin aktif etkileşim deneyimlerini destekler. Öğrencinin sorunlarına, deneyimlerine ve araştırmalarına önem verir ve öğretmenlerin öğrenmesini destekler. 
Yansıtıcı zekâ. Temel becerileri ve genelde okulun etkinliğini yönetme süreçlerini, özelde öğrenenlerin kazanımlarını içerir. Bu süreçlerin yansıtılması ve öğrencilerin kazanımları önemsenir.

Pedagojik zekô. Okulun öğrenen bir örgüt olarak kendini ifade etmesi ile tanımlanır. Katı bir kurum olmak yerine okulun öğrenme ve öğretme süreçlerinin denetimle geliştirilmesi amaçlanır. Öğrenme ve öğretme arasındaki ilişki dinamiktir ve bu nedenle belirlenecek yol haritaları amaçlar ile uyumlu olmalıdır.

Mesleksel zekâ. Bu zeka türünde, sınıf içi etkinlerin geliştirilmesi için okuldaki tüm üyeler birlikte çalışma kapasitesine sahiptir. Öğretmenlerin mesleki gelişimlerinin sürekli olması ve farklı yöntemler ile desteklenmesi beklenir. Okulun gelişmesi ve öğretmenlerin öğrenmesi arasındaki ilişkiye ve değişimin ana etmenlerinin öğretmenler olduğuna vurgu yapılır.

Duygusal zekâ. Öğrencilerin ve öğretmenlerin deneyimledikleri ve değer verdikleri, duyguları içeren bir okul yapısı ile ilişkilidir.

Spritüal (ruhsal, ruhani) zekô. Bu zeka türüne göre manevi değerler yaratıcılığın itici gücüdür. Araştırma, gözlemler, empati, sanatsal ifadeler, disiplinli çalışma gibi kavramlar çerçevesinde bireylerin birbirine ve hayata açılmalarını sağlar. Spritüal, bireylerin deneyimledikleri umudu, sabrı, cesareti, barışı ve hayatın amacını işe koşan bir zeka türüdür.

Etik zekâ. Bu zekâ türünde okulun amaçları doğrultusunda belirlenen değer ve inanç sistemine göre bireylerin sahip olduğu hakları vurgular. Okul üyelerinin adalet, dürüstlük ve bireysel amaç ve prensiplerini belirlemelerini sağlar. Öğrenciler için uygun ve kapsamlı bir öğretim programı içeriğini sağlayan tutumları ve kaynakların kullanımı ile ilgilidir.

Erçetin (2004b), örgütsel zeka kapsamında tanımladığı yetenekleri, eğitim örgütleri için okullarda örgütsel zekanın eylemsel boyutları olarak tanımlamış ve bu boyutların okulların zeki örgütler için kullanılabileceğini belirtmiştir. Bu eylemsel alt boyutlar şu şekilde açıklanmıştır (Erçetin, 2004b):

1. Eylem ve tepkide çabukluk: Hızlı kararlar alınması, çevresel ve içsel uyaranların en kısa zamanda algılanması, değişimlere hızlı ve doğru tepki vermesi,

2. Değişen durumlara uyarlanabilme: Farklılaşan koşullarda yeni dengelerin oluşturulabilmesi, oluşan çeşitli karışıklıklara uygun politika ve stratejilerin geliştirilmesi,

3. İşleyiş̧te esnek ve rahat olabilme: Örgütün işleyişine ilişkin kuralların gerektiğinde değiştirilebilir nitelikte olması, çalışanların bunu hissetmesi, görev tanımlarının iş birliği yapacak esneklikte olması, bürokratik işlemlerin örgütsel hızı azaltmayacak düzeyde yapılması, çalışanların kimi konularda seçim yapabilecek özgürlüğe sahip olmaları,

4. Sezebilme ve öngörülü olabilme: Örgütlerde gerçekleşen ya da gerçekleşmesi olası durum ve olayların fark edilmesi, hissedilmesi, daha farklı bir ifade ile "duygusal zekânın örgütsel düzeyde kullanılması,

5. Açık fikirli olabilme: Örgütteki tüm bireylerin fikir, öneri ya da eleştirilerini açıkça ifade edebilmesi,

6. Hayal gücünü kullanabilme: Bireysel yaratıcılı̆ıı, örgütsel etkililiği arttırma amaçlı kullanılması

7. Yenilenebilme: Örgütlerin gelişmesini sağlayacak yeni bilgi ve teknolojilerin kullanılması olarak tanımlanmaktadır.

Okulların çevresel değişiklikleri anlama, bu değişime uyum sağlama ve gelecekte etkili olacak stratejiler geliştirme becerileri örgütsel zekalarının geliştirilmesinin önemini vurgulamaktadır. Öngörme, hızlı tepki gösterme, uyarlanma, esneklik, yaratıcılık ve yenilenme becerileri okulların örgütsel zeka düzeylerini geliştirmelerinde iti güç sağlayan özellikler olarak düşünülebilir.

\subsection{Amaç}


Örgütlerin sürekli değişim yaşayan çevreye uyum sağlayabilmeleri için, bilgiyi üreterek işe koşmaları beklenmektedir. Organizma metaforu ile tanımlanabilen örgüt sistemlerinin zeki olmasının önemi, bu sahip oldukları zekayı davranışlarına yansıtma ve hayatta kalma potansiyelleri ile ilgilidir. Dolayısıyla, örgütün zekâsının ve onu etkileyen faktörlerin belirlenebilmesi oldukça önemlidir.

Bu çalışma, okulların değişen koşullar içerisinde bilgi üretme ve kullanma becerilerinde önemli bir etken olduğunu düşündüğümüz örgütsel zekanın ve alt boyutlarının etki ve önemini tespit etmek amacıyla yapılmıştır. Ayrıca cinsiyet, kıdem, çalışma süreleri, yaş gibi değişkenler açısından örgütsel zekanın değerlendirilmesi ile ilgili gruplararası karşılaştıııma imkanı sunulmaktadır. Araştırma kapsamında çalışılan ilkokulun durumunun tespiti, örgütsel zekâ üzerinde etkili olan bu değişkenlerin belirlenmesi ve süreci nasıl etkilediğinin anlaşılması açısından önemlidir.

Bu bağlamda çalışmanın amacl; belirlenen ilkokulda görev yapan öğretmen ve yönetici görüşlerine göre, örgütsel zekâ ve örgütsel zekânın eylemsel boyutlarının düzeylerini ortaya koymak ve bu görüşlerin yaş, cinsiyet, kıdem, okuldaki çalışma yılı ve eğitim durumları gibi demografik değişkenlere farklılaşıp farklılaşmadığını incelemektir.

\subsection{Problem}

Araştırmanın amacı doğrultusunda aşağıdaki sorulara yanıt aranmıştır:

1. İlkokulun örgütsel zekâsı ve örgütsel zekânın eylemsel boyutları ne düzeydedir?

illkokulun örgütsel zekâ ve örgütsel zekânın eylemsel boyutları cinsiyet, öğrenim düzeyi, branş, yaş, kıdem, öğrenim durumu ve çalışma süresine göre farklılaşmakta mıdır?

\section{YÖNTEM}

Bir ilkokuldaki yönetici ve öğretmenlerin görüşlerine göre örgütsel zekâ düzeylerini belirlemeyi ve demografik değişkenlere göre örgütsel zekâ ve eylemsel boyutlarının düzeylerine göre farklılaşıp farklılaşmadığı incelemeyi amaçlayan bu çalışmada, nicel yöntemler kullanılarak verilerin toplanması ve analiz edilmesi yoluna gidilmiştir.

\section{1 Çalışma Grubu}

Araştırmanın çalışma grubunu, 2018-2019 eğitim-öğretim dönemi içerisinde, Ankara ili Çankaya ilçesindeki araştırmaya gönüllü olarak katılmayı kabul eden bir ilkokulda görev yapan 48 kişi oluşturmaktadır. Çalışma grubunun seçiminde amaçlı örnekleme yöntemlerinden, maksimum çeşitlilik yöntemi tercih edilmiştir. Bunun nedeni ise, göreli olarak küçük bir örneklem oluşturmak ve bu örneklemde çalışılan probleme taraf olabilecek bireylerin çeşitliliğini maksimum derecede yansıtmaktır (Yıldırım ve Şimşek, 2005). Tablo 1'de çalışma grubuna ait bilgiler sunulmuştur.

Tablo 1. Çalışma Grubuna Ait Bilgiler $(n=48)$

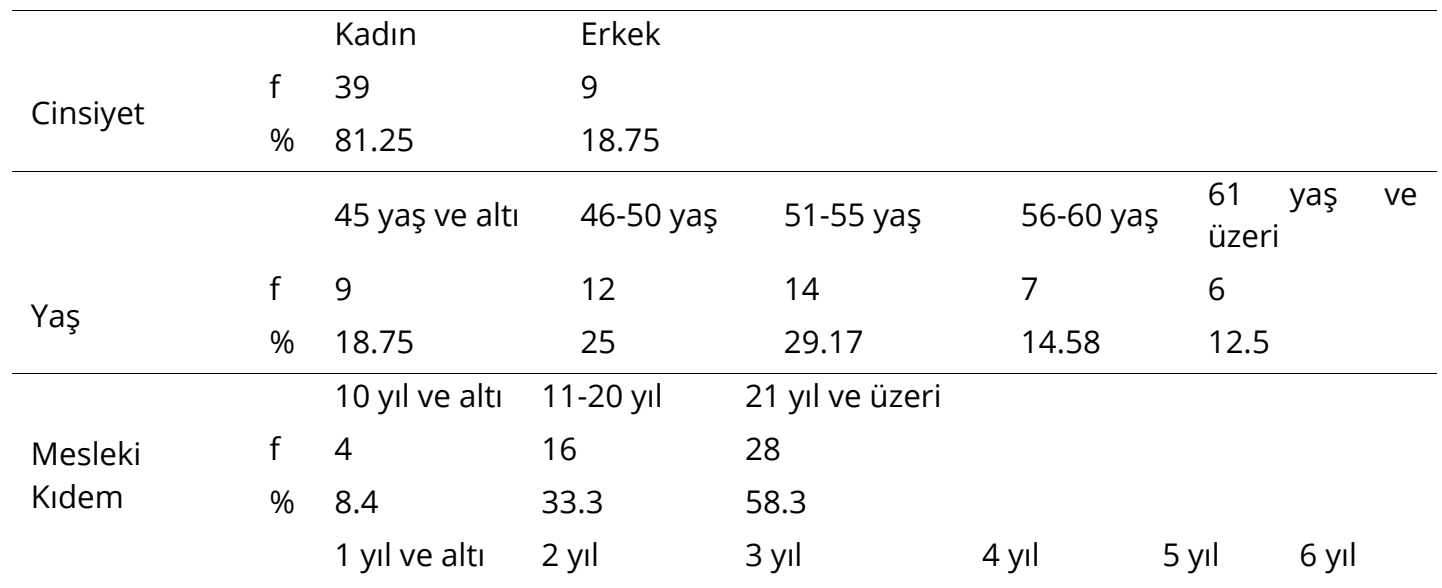




\begin{tabular}{|c|c|c|c|c|c|c|c|c|}
\hline \multirow{2}{*}{$\begin{array}{l}\text { Okulda } \\
\text { Çalışma Yılı }\end{array}$} & $f$ & 15 & 3 & 5 & & 8 & 3 & $\begin{array}{l}14 \\
29 ?\end{array}$ \\
\hline & $\%$ & 31.25 & 0.25 & 10.4 & & 16.65 & 0.25 & \\
\hline \multirow{3}{*}{$\begin{array}{l}\text { Eğitim } \\
\text { Durumu }\end{array}$} & & Ön Lisans & Lisans & & $\begin{array}{l}\text { Yüksek } \\
\text { Lisans }\end{array}$ & & & \\
\hline & $f$ & 13 & 33 & & 2 & & & \\
\hline & $\%$ & 27.08 & 68.75 & & 4.17 & & & \\
\hline \multirow[b]{3}{*}{ Branş } & & Sinıf & Okul Öncesi & Alan & & & & \\
\hline & f & 36 & 5 & 7 & & & & \\
\hline & $\%$ & 75 & 10.42 & 14.58 & & & & \\
\hline
\end{tabular}

Tablo 1 incelendiğinde katılımcıların 39'unun kadın, 9'unun erkek olduğu; ayrıca çoğunluğunun 46 ve 55 yaş aralığında oldukları belirlenmiştir. Öğretmen ve yöneticilerin mesleki kıdemleri 11 yıl ve üzerinde iken çoğunluğu 21 yıl ve üzeri $(\% 58,3)$ kıdeme sahiptir. Uygulama yapılan ilkokuldaki çalışma yılları en fazla 1 yıl ve altı $(\% 31,25)$ ve 6 yıl $(\% 29,2)$ olduğu görülmektedir. 2 katılımcı yüksek lisans derecesine sahiptir ve 33 katılımcı ise üniversite mezunu (lisans) olduklarını bildirmişlerdir. Katılımcıların branşlarına bakıldığında ise sınıf öğretmenleri (1., 2., 3. ve 4. sınıf) çalışma grubunun \%75'ini, alan öğretmenleri (Ingilizce, Din kültürü ve ahlak bilgisi, Rehber öğretmen ve okul yöneticileri) \%14,5'ini, okul öncesi öğretmenleri \%6,2'sini oluşturmaktadır.

\subsection{Veri Toplama Yöntemi}

Araştırmada araştırmacıların izinleri alınarak "Çok Boyutlu Örgütsel Zekâ Ölçeği" kullanılmıştır. Bu ölçek ile katılımcıların örgütsel zekâ ve örgütsel zekânın eylemsel boyutları ile ilgili algılarına ilişkin var olan durum ortaya konulmuştur. Ölçeğin ilk uygulaması Erçetin $(2001,2004)$ tarafından geliştirilmiştir ve yeniden uyarlanmıştır (Erçetin, Çetin ve Potas, 2007; Potas, Erçetin ve Koçak, 2010). Örgütsel Zekâ Aracının son düzenlenmesi 2015 yılında Erçetin, Potas ve Açıkalın tarafından gerçekleştirilmiştir. Ölçek 5'li likert tipi, yedi boyut ve toplam 67 maddeden oluşmaktadır. Her bölümün maddelerine verilen yanıtların toplamı bölüm puanlarını ve bütün bölümlerin puanlarının toplamları da genel puanı oluşturmaktadır. Toplam puanların madde sayısına göre ortalaması alınarak, beş üzerinden değerlendirmesi yapılmaktadır. Ölçekten alınan puan ortalamaları; 1.001.80 puan aralığı "çok düşük düzey örgütsel zekâ", 1,81-2,60 puan aralığı "düşük düzey örgütsel zekâ", 2.61-3.40 puan aralığı "orta düzey örgütsel zekâ", 3.41-4.20 puan aralığı "yüksek düzey örgütsel zekâ", 4.21-5.00 puan aralığı "çok yüksek düzey örgütsel zekâ" olarak yorumlanmaktadır. Ölçeğin Cronbach alfa güvenirlik katsayısı her bir boyut için sırasıyla; Eylem ve tepkide çabukluk 0.93, Değişen durumlara uyum sağlama I 0.91, İşleyişte esnek ve rahat olabilme 0.91, Paydaşlarla etkili iletişim 0.95, Sezebilme ve öngörebilme 0.96, Hayal gücünü kullanabilme ve Yaratıcılık 0.93, Değişen durumlara uyum sağlama II 0.95 olarak belirlenmiştir. Ölçeğin bütününe ilişkin Cronbach alfa güvenirlik katsayısı ise 0.99 'dur (Potas, Erçetin, Koçak, 2010). Ölçeğin farklı uyarlamaları (Erçetin, 2001; Erçetin, 2004b; Erçetin, Çetin ve Potas, 2007; Erçetin, Potas ve Açıkalın, 2015) da dâhil olmak üzere Eylem ve tepkide çabukluk, Değişen durumlara uyarlanabilme, iş̧leyişte esnek ve rahat olabilme, Sezebilme ve öngörülü olabilme, Açık fikirli olabilme, Hayal gücünü kullanabilme ve Yenilenebilme boyutları kullanılmıştır.Çok boyutlu örgütsel zekâ ölçeği"nin giriş kısmında katılımcılara ölçek ile ilgili uygulama yönergesi verilerek, örnek bir maddenin işaretlenmesine ilişkin bilgilendirme yapılmıştır. Yine ölçek kapsamında katılımcılara ait demografik bilgiler istenmiştir.

\subsection{Verilerin Analizi}

Araştırmanın alt problemlerinin çözümlenmesi için elde edilen nicel verilerin analizinde frekans, aritmetik ortalama, standart sapma gibi istatistiksel teknikler içeren nicel analiz yöntemleri kullanılmıştır.

İlkokulun yedi alt boyutta ve genel örgütsel zekâ düzeylerini belirlemek amacılla tüm boyutlara ilişkin ve genel toplam puanlar soru sayısına bölünmüştür. Boyutlara ve genel örgütsel zekâ 
düzeylerine ilişkin ortalama puanlar belirlenerek, beşli derecelendirmeye uygun biçime getirilmiştir. Ortalama puanlar beşli dereceleme ölçeğinde dört aralık için $(5-1=4)$ ve $(4 / 5=0.80)$ hesaplanan aralığa göre örgütsel zekâ düzeyleri belirlenmiştir. Buna göre düzeylerin puan aralıkları "çok düşük düzey örgütsel zeka" ve "çok yüksek düzey örgütsel zeka" aralığında belirlenmiştir. Ölçekten elde edilen nicel veriler, cinsiyet gibi iki kategorili değişkenlerin karşılaştırılmasında t-testi ile incelenmiştir. Eğitim durumu ve branş gibi ikiden çok kategorili olan değişkenlerde Tek Yönlü Varyans Analizi (ANOVA) kullanılmıştır. Etkisi test edilen bağımsız değişkenin dışında bağımlı değişken ile ilişkisi olan ve ortak değişken olarak isimlendirilen bir başka değişkenin ya da değişkenlerin istatistiksel olarak kontrol edilmesini sağlamak amacıyla kovaryans analizi (ANCOVA) kullanılmıştır. Buradaki amaç bağımlı değişkenden, ortak değişkenden kaynaklanan farkları elemek ve bağımlı değişkendeki değişmenin, bağımsız değişkenden kaynaklanıp kaynaklanmadığını incelemektir. Normal dağılım incelemeleri ve varyansların homojenliği test edilmiştir. Yapılan bu kontrol sonucunda varsayımlar sağlandığından $t$ testi ve tek yönlü varyans analizlerinin yapılmasının uygun olduğuna karar verilmiştir. Tek Yönlü Varyans Analizi sonucunda ortaya çıkan anlamlı farklılıklar var ise hangi gruplar arasında olduğunun belirlenmesi için LSD çoklu karşılaştırma testi uygulanmıştır. Ancova içinde artıkların normal dağılım gösterip göstermediğine, ortak değişken ve bağımsız değişkenin her seviyesinde bağımlı değişken ile doğrusal olarak ilişkisine, ortak değişkenler arasındaki korelasyona, eş-varyansliliğa ve varyanslarin homojenliğine bakılmıştır. Bunun sonucunda da Ancova yapilmasinin uygun olduğu belirlenmiştir.

\section{BULGULAR}

\section{1 Öğretmen ve Yönetici Görüşlerine Göre İlkokulun Örgütsel Zeka Düzeyi}

Bu bölümde araştırmaya katılan okul yöneticileri ve öğretmenlerin algılarına göre, ilkokulun kurumsal ve yönetsel kapasitesine yönelik çok boyutlu örgütsel zekâ düzeylerine ilişkin bulgular sunulmaktadır. Okul yöneticileri ve öğretmenlerin görev yaptıkları okulun örgütsel zeka ve alt boyutlarına ilişkin betimsel istatistikler Tablo 2'de verilmiştir.

Tablo 2. Öğretmenlerin Örgütsel Zekâ ve Eylemsel Boyutlarına Illişkin Genel Betimsel İstatistikler $(n=48)$

\begin{tabular}{lccc}
\hline $\begin{array}{l}\text { Örgütsel Zeka ve Eylemsel Alt } \\
\text { Boyutları }\end{array}$ & $\bar{X}$ & ss & Düzey \\
\hline Değişen Durumlara Uyum Sağlama I & 3.68714 & .857665 & Yüksek \\
Paydaşlarla Etkili Iletişim & 3.01654 & 1.016151 & Orta \\
Eylemde ve Tepkide Çabukluk & 3.72378 & 1.861791 & Yüksek \\
$\begin{array}{l}\text { Sezebilme ve Öngörebilme } \\
\text { Hayal Gücünü Kullanabilme ve }\end{array}$ & 3.03039 & 1.095409 & Orta \\
$\begin{array}{l}\text { Yaratıclık } \\
\text { Işleyişte Esnek ve Rahat Olabilme }\end{array}$ & 3.38931 & .963040 & Orta \\
Değişsen Durumlara Uyum Sağlama II & 3.47531 & 1.175374 & Yüksek \\
Genel Örgütsel Zeka Düzeyi & 3.38767 & .455431 & Yüksek \\
\hline
\end{tabular}

Tablo 2'de katılımcıların ilkokulun örgütsel zekânın eylemsel boyutlarına ilişkin algıları incelendiğinde, öğretmen ve yöneticilerin genel örgütsel zeka düzeyi algının orta düzey olduğu $(\bar{X}=3.38)$, örgütsel zekanın eylemsel alt boyutlarında ise tüm katılımcıların algılarının yüksek ve orta düzeyde olduğu söylenebilir. Örgütsel zekanın eylemsel alt boyutlarında en yüksek ortalama 
Eylemde ve Tepkide Çabukluk boyutunda $(\bar{X}=3.72)$, en düşük ortalamanın ise Paydaşlarla Etkili iletişim $(\bar{X}=3.01)$ boyutunda olduğu görülmektedir. Benzer şekilde Turan (2017) çalışmasında, öğretmenlerin görev yaptıkları okulların örgütsel zekâ düzeyine ilişkin algılarının yüksek düzeyde olduğu ve en yüksek ortalamanın da Eylemde ve Tepkide Çabukluk boyutunda saptandığını vurgulamıştır. Sonuç olarak okulun zekâ düzeyine ilişkin öğretmen ve yönetici algılarının Değişen Durumlara Uyum Sağlama I ( $\bar{X}=3.68)$, Eylemde ve Tepkide Çabukluk $(\bar{X}=3.72)$, işleyişte Esnek ve Rahat Olabilme $(\bar{X}=3.44)$ ve Değişen Durumlara Uyum Sağlama II ( $\bar{X}=3.47)$ alt boyutlarında yüksek düzeyde olduğu görülmektedir.

\section{2 Öğretmen ve Yönetici Görüşlerine Göre Örgütsel Zekâ Düzeyinin Belirli Değişkenlere Göre İncelenmesi}

Bu bölümde, ilkokulun örgütsel zekâ düzeyi cinsiyet, öğrenim düzeyi, branş, okuldaki hizmet yıll, kıdem ve yaş değişkenlerine göre incelenmiş ve bulgular aşağıda sunulmuştur. Kıdem, yaş ve çalışma sürelerine göre örgütsel zekanın tüm boyutlarına ilişkin yapılan varyans analizleri sonucunda, istatistiksel olarak anlamlı farklılık olmadığı belirlenmiştir. Bu başlık altında anlamlı farklılık olduğu belirlenen cinsiyet, öğrenim düzeyi ve branş değişkenlerine ilişkin Anova ile yaş, kıdem ve çalışma süresinin ortak değişken olarak atanmasıyla gerçekleştirilen Ancova analizi sonucunda ulaşılan bulgulara yer verilmiştir.

Katılımcıların cinsiyetlerine göre genel örgütsel zeka algıları arasında farklılık olup olmadığını belirlemek üzere t-testi yapılmıştır. Cinsiyete göre betimsel istatistikler ve t-testi sonuçları Tablo 3'te sunulmuştur.

Tablo 3. Katılımcıların Cinsiyetlerine Göre Örgütsel Zekâ Algılarına İlişkin Betimsel İstatistikler ve ttesti sonuçları

\begin{tabular}{|c|c|c|c|c|c|c|}
\hline & & $\mathrm{N}$ & $\bar{X}$ & SS & $\mathrm{t}$ & $p^{*}$ \\
\hline \multirow{2}{*}{$\begin{array}{l}\text { Değişen Durumlara Uyum } \\
\text { Sağlama I }\end{array}$} & Kadın & 39 & 3.9982 & .5586 & \multirow{2}{*}{8.008} & \multirow{2}{*}{.000} \\
\hline & Erkek & 9 & 2.3390 & .5680 & & \\
\hline \multirow{2}{*}{ Paydaşlarla Etkili Illetişim } & Kadın & 39 & 3.0735 & 1.018 & \multirow{2}{*}{.807} & \multirow{2}{*}{.424} \\
\hline & Erkek & 9 & 2.7693 & 1.025 & & \\
\hline \multirow{2}{*}{$\begin{array}{l}\text { Eylemde ve Tepkide } \\
\text { Çabukluk }\end{array}$} & Kadın & 39 & 2.9773 & .5849 & \multirow{2}{*}{-3.502} & \multirow{2}{*}{.001} \\
\hline & Erkek & 9 & 3.7052 & .4332 & & \\
\hline \multirow{2}{*}{ Sezebilme ve Öngörebilme } & Kadın & 39 & 3.3452 & .9505 & \multirow{2}{*}{5.149} & \multirow{2}{*}{.000} \\
\hline & Erkek & 9 & 1.6659 & .4247 & & \\
\hline \multirow{2}{*}{$\begin{array}{l}\text { Hayal Gücünü } \\
\text { Kullanabilme ve Yaratıcılık }\end{array}$} & Kadın & 39 & 3.3288 & .9933 & \multirow{2}{*}{-.904} & \multirow{2}{*}{.371} \\
\hline & Erkek & 9 & 3.6513 & .8163 & & \\
\hline \multirow{2}{*}{$\begin{array}{l}\text { Işleyişte Esnek ve Rahat } \\
\text { Olabilme }\end{array}$} & Kadın & 39 & 3.4304 & 1.2158 & \multirow{2}{*}{-.230} & \multirow{2}{*}{.819} \\
\hline & Erkek & 9 & 3.5313 & 1.0419 & & \\
\hline \multirow{2}{*}{$\begin{array}{l}\text { Değişen Durumlara Uyum } \\
\text { Sağlama II }\end{array}$} & Kadın & 39 & 3.3539 & 1.2048 & \multirow{2}{*}{-1.494} & \multirow{2}{*}{.142} \\
\hline & Erkek & 9 & 3.8066 & .9987 & & \\
\hline \multirow{2}{*}{$\begin{array}{l}\text { Genel Örgütsel Zeka } \\
\text { Düzeyi }\end{array}$} & Kadın & 39 & 3.3582 & .4612 & \multirow{2}{*}{1.602} & \multirow{2}{*}{.116} \\
\hline & Erkek & 9 & 3.0947 & .3556 & & \\
\hline
\end{tabular}

$\star_{p}<.05$

Tablo 3 incelendiğinde katılımcıların görev yaptıkları ilkokulun genel örgütsel zekâ düzeyine yönelik algılarının, cinsiyet değişkenine göre istatistiksel olarak anlamlı bir farklılık göstermediği, ancak Değişen Durumlara Uyum Sağlama I, Eylemde ve Tepkide Çabukluk ve Sezebilme ve Öngörebilme alt boyunda istatistiksel olarak anlamlı bir şekilde farklılaştığını göstermektedir. Katılımcıların Değişen Durumlara Uyum Sağlama I alt boyutunda aldığı puanlara bakıldığında, kadın katıımcıların 
( $\bar{X}=3.99 ;$ yüksek düzey) erkek katılımcılara ( $\bar{X}=2.33$; düşük düzey) göre daha yüksek bir algıya sahip oldukları söylenebilir. Katılımcıların Eylemde ve Tepkide Çabukluk alt boyutunda aldığı puanlara bakıldığında, erkek katılımcıların ( $\bar{X}=3.70$; yüksek düzey) kadın katılımcılara ( $\bar{X}=2.97$; orta düzey) göre daha yüksek bir algıya sahip oldukları söylenebilir. Katılımcıların Sezebilme ve Öngörebilme alt boyutunda aldığı puanlara bakıldığında, kadın katılımcıların $(\bar{X}=3.34$; orta düzey) erkek katılımcılara ( $\bar{X}=1.66$; çok düşük düzey) göre daha yüksek bir algıya sahip oldukları söylenebilir. Turan (2017) çalışmasında genel örgütsel zekâ algısına ilişkin katılımcı görüşlerinin, cinsiyetlerine göre farklılaşmadığını vurgularken, araştırma bulgularını destekler nitelikte Çakır (2008), öğretmenlerin algılarının, örgütsel zekânın eylemsel boyutlarından eylem ve tepkide çabukluk ve sezebilme ve öngörebilme boyutlarında istatistiksel olarak anlamlı farklılık ortaya çıktığını belirtmektedir.

Tablo 4'te örgütsel zekânın eylemsel boyutlarına ilişkin katılımcıların görüşleri arasında öğrenim düzeylerine göre fark olup olmadığı sorusunda cevap aranmış ve bulgular aşağıda verilmiştir.

Tablo 4. Katılımcıların Öğrenim Düzeylerine Göre Örgütsel Zekâ Algılarına İlişkin Betimsel İstatistikler ve Varyans Analizleri (ANOVA)

\begin{tabular}{|c|c|c|c|c|c|c|c|}
\hline & & $\mathrm{N}$ & $\bar{X}$ & ss & $\mathrm{F}$ & $p^{*}$ & Anlamlı Fark \\
\hline \multirow{3}{*}{$\begin{array}{l}\text { Değişen Durumlara } \\
\text { Uyum Sağlama I }\end{array}$} & Ön Lisans & 13 & 4.028 & .8238 & \multirow{3}{*}{6.692} & \multirow{3}{*}{.003} & Ön lisans-Yüksek \\
\hline & Lisans & 33 & 3.661 & .7600 & & & Lisans \\
\hline & $\begin{array}{l}\text { Yüksek } \\
\text { Lisans }\end{array}$ & 2 & 1.899 & .1302 & & & $\begin{array}{l}\text { Lisans-Yüksek } \\
\text { Lisans }\end{array}$ \\
\hline \multirow{3}{*}{$\begin{array}{l}\text { Paydaşlarla Etkili } \\
\text { Iletişim }\end{array}$} & Ön Lisans & 13 & 3.283 & 1.0073 & \multirow{3}{*}{1.532} & \multirow{3}{*}{.227} & \\
\hline & Lisans & 33 & 2.973 & 1.0101 & & & \\
\hline & $\begin{array}{l}\text { Yüksek } \\
\text { Lisans }\end{array}$ & 2 & 1.989 & .7784 & & & \\
\hline \multirow{3}{*}{$\begin{array}{l}\text { Eylemde ve Tepkide } \\
\text { Çabukluk }\end{array}$} & Ön Lisans & 13 & 3.186 & 1.8130 & \multirow{3}{*}{2.478} & \multirow{3}{*}{.095} & \\
\hline & Lisans & 33 & 3.032 & 1.7709 & & & \\
\hline & $\begin{array}{l}\text { Yüksek } \\
\text { Lisans }\end{array}$ & 2 & 3.990 & 1.6755 & & & \\
\hline \multirow{3}{*}{$\begin{array}{l}\text { Sezebilme ve } \\
\text { Öngörebilme }\end{array}$} & Ön Lisans & 13 & 3.3473 & 1.0577 & \multirow{3}{*}{3.446} & \multirow{3}{*}{.041} & Ön lisans-Yüksek \\
\hline & Lisans & 33 & 3.012 & 1.0519 & & & Lisans \\
\hline & $\begin{array}{l}\text { Yüksek } \\
\text { Lisans }\end{array}$ & 2 & 1.2736 & .2599 & & & $\begin{array}{l}\text { Lisans-Yüksek } \\
\text { Lisans }\end{array}$ \\
\hline \multirow{3}{*}{$\begin{array}{l}\text { Hayal Gücünü } \\
\text { Kullanabilme ve } \\
\text { Yaratıcılık }\end{array}$} & Ön Lisans & 13 & 2.093 & .4333 & \multirow{3}{*}{50.876} & \multirow{3}{*}{.000} & \multirow{3}{*}{$\begin{array}{l}\text { Lisans-Ön lisans } \\
\text { Yüksek Lisans-Ön } \\
\text { lisans }\end{array}$} \\
\hline & Lisans & 33 & 3.893 & .5887 & & & \\
\hline & $\begin{array}{l}\text { Yüksek } \\
\text { Lisans }\end{array}$ & 2 & 3.496 & .1431 & & & \\
\hline \multirow{3}{*}{$\begin{array}{l}\text { Işleyişte Esnek ve Rahat } \\
\text { Olabilme }\end{array}$} & Ön Lisans & 13 & 1.811 & .5440 & \multirow{3}{*}{63.159} & \multirow{3}{*}{.000} & \multirow{3}{*}{$\begin{array}{l}\text { Lisans-Ön lisans } \\
\text { Yüksek Lisans-Ön } \\
\text { lisans }\end{array}$} \\
\hline & Lisans & 33 & 4.047 & .6342 & & & \\
\hline & $\begin{array}{l}\text { Yüksek } \\
\text { Lisans }\end{array}$ & 2 & 4.223 & .7948 & & & \\
\hline \multirow{3}{*}{$\begin{array}{l}\text { Değişen Durumlara } \\
\text { Uyum Sağlama II }\end{array}$} & Ön Lisans & 13 & 1.738 & .5078 & \multirow{3}{*}{104.306} & \multirow{3}{*}{.000} & \multirow{3}{*}{$\begin{array}{l}\text { Lisans-Ön lisans } \\
\text { Yüksek Lisans-Ön } \\
\text { lisans }\end{array}$} \\
\hline & Lisans & 33 & 4.086 & .5156 & & & \\
\hline & $\begin{array}{l}\text { Yüksek } \\
\text { Lisans }\end{array}$ & 2 & 4.681 & .3777 & & & \\
\hline
\end{tabular}




\begin{tabular}{lllllll}
\hline & Ön Lisans & 13 & 2.784 & .3073 & & \\
Genel Örgütsel Zeka & Lisans & 33 & 3.529 & .3138 & 27.583 & .000 Lisans-Ön lisans \\
Düzeyi & $\begin{array}{l}\text { Yüksek } \\
\text { Lisans }\end{array}$ & 2 & 3.079 & .1731 & & \\
& & & & & & \\
\hline
\end{tabular}

${ }^{*} \mathrm{p}<.05$

Tablo 4'de görüldüğü gibi öğretmenlerin görev yaptıkları ilkokulda genel örgütsel zekâ ve eylemsel alt boyutlarına ilişkin algılarının, öğretmenlerin öğrenim düzeyine göre istatistiksel olarak anlamlı bir şekilde farklılaştığını göstermektedir. Bu farklılı̆ın hangi grup ya da gruplardan kaynaklandığını belirlemek üzere, varyansların homojen olması durumunda kullanılan LSD çoklu karşılaştırma testi yapılmıştır.

Lisans mezunu ( $\bar{X}=3.52$, yüksek düzey) katılımcıların, ön lisans mezunu ( $\bar{X}=2.78$, orta düzey) ve yüksek lisans derecesi sahibi ( $\bar{X}=3.07$, orta düzey) katılımcılara göre ilkokulun örgütsel zeka düzeyine ilişkin algıları daha yüksektir. Bu farkın, lisans ve ön lisans mezunu katılımcılar arasında istatistiksel olarak anlamlı olduğu ve lisans mezunu öğretmen ve yöneticilerin ön lisans mezunu öğretmen ve yöneticilere kıyasla daha yüksek örgütsel zeka algısına sahip oldukları söylenebilir. Örgütsel zekanın eylemsel alt boyutlarına ilişkin algılarında, Paydaşlarla Etkili i̇letişim ve Eylemde ve Tepkide Çabukluk boyutları dışındaki tüm boyutlarda istatistiksel olarak anlamlı fark tespit edilmiştir.

Kıdem, yaş ve çalışma sürelerine göre örgütsel zekanın tüm boyutlarına ilişkin yapılan varyans analizleri sonucunda, istatistiksel olarak anlamlı farklılık olmadığı belirlendiğinden, katılımcıların kıdem, yaş ve çalışma süreleri varyans analizi yapmak için kategorik hale getirilmiştir. Kıdem, yaş ve çalışma süreleri değişkenlerinin yapısı bozulmadan ortak değişken olarak Ancova modeline alınmıştır. Oluşturulan modellerin analiz sonuçları (ANCOVA) Tablo 5, 6, 7 ve 9'da verilmektedir. Tablo 5'de katılımcıların öğrenim düzeylerine göre örgütsel zekânın değişen durumlara uyum sağlama I boyutuna ilişkin varyans analizleri ve analiz sonucunda bulunan farkın kaynağına yer verilmiştir.

Tablo 5. Katılımcıların Öğrenim Düzeylerine Göre Örgütsel Zekânın Değişen Durumlara Uyum Sağlama I Boyutuna iliş̧kin Varyans Analizleri (ANCOVA)

\begin{tabular}{|c|c|c|c|c|c|c|}
\hline $\begin{array}{l}\text { Varyansın } \\
\text { Kaynağı }\end{array}$ & $\begin{array}{c}\text { Kareler } \\
\text { Ortalaması }\end{array}$ & $\mathrm{Sd}$ & $\begin{array}{c}\text { Ortalama } \\
\text { Kareler }\end{array}$ & $\mathrm{F}$ & $\mathrm{p}$ & Anlamlı Fark \\
\hline 气 Yaş & 6.100 & 1 & 6.100 & 12.715 & .001 & $\begin{array}{l}\text { Ön Lisans- } \\
\text { Yüksek } \\
\text { Lisans }\end{array}$ \\
\hline $\begin{array}{l}\frac{1}{\pi} \\
\frac{1}{\pi} \\
2 \\
\frac{0}{0}\end{array}$ & 4.236 & 1 & 4.236 & 8.829 & .005 & $\begin{array}{l}\text { Lisans- } \\
\text { Yüksek } \\
\text { Lisans }\end{array}$ \\
\hline $\begin{array}{l}\text { Çalışma } \\
\text { süresi }\end{array}$ & .376 & 1 & .376 & .784 & .381 & \\
\hline $\begin{array}{l}\text { Öğrenim } \\
\text { Düzeyi }\end{array}$ & 4.095 & 2 & 2.048 & 4.268 & .021 & \\
\hline Hata & 20.149 & 42 & .480 & & & \\
\hline Toplam & 687.133 & 48 & & & & \\
\hline
\end{tabular}

$\star_{p}<.05$

Yaş, kıdem ve çalışma süresi gibi analiz sonuçlarında istatistiksel olarak anlamlı çıkmayan değişkenlerin ortak değişken olarak değerlendirilmesinden sonra elde edilen sonuçları içeren Tablo 5 incelendiğinde, oluşturulan modelin anlamlı çıktığı $(F=6.013, p<0.05)$ sonucuna ulaşıımıştır. Bu durumda yaş ve kıdemin değişkenlerinin Değişen Durumlara Uyum Sağlama I boyutuna ilişkin 
oluşturulan modelde anlamlı çıktığı görülmektedir. Bir diğer deyişle, Değişen Durumlara Uyum Sağlama I boyutunda katılımcıların öğrenim düzeyindeki farklılaşma, yaş ve kıdem değişkenlerinden etkilenmektedir (Uyarlanmış $R^{2}=\% 34.8$ ). Bu koşullarda ön lisans mezunu ( $\bar{X}=3.88$, yüksek düzey) katılımcıların yüksek lisans mezunu ( $\bar{X}=2.27$, düşük düzey) katılımcılara ve lisans mezunu ( $\bar{X}=3.69$, yüksek düzey) katılımcıların yüksek lisans mezunu katılımcılara göre algılarının daha yüksek olduğu söylenebilir.

Tablo 6'da katılımcıların öğrenim düzeylerine göre örgütsel zekânın işleyiş̧te esnek ve rahat olabilme boyutuna ilişkin yaş, kıdem ve çalışma süresinin ortak değişken olarak alındığı varyans analizi ve analiz sonucunda bulunan farkın kaynağına yer verilmiştir.

Tablo 6. Katılımcıların Öğrenim Düzeylerine Göre Örgütsel Zekânın İşleyişte Esnek ve Rahat Olabilme Boyutuna İlişkin Varyans Analizleri (ANCOVA)

\begin{tabular}{|c|c|c|c|c|c|c|c|}
\hline \multicolumn{2}{|c|}{$\begin{array}{l}\text { Varyansın } \\
\text { Kaynağı }\end{array}$} & \multirow{2}{*}{$\begin{array}{c}\begin{array}{c}\text { Kareler } \\
\text { Ortalaması }\end{array} \\
1.670\end{array}$} & \multirow{2}{*}{$\frac{S d}{1}$} & \multirow{2}{*}{$\begin{array}{c}\begin{array}{c}\text { Ortalama } \\
\text { Kareler }\end{array} \\
1.670\end{array}$} & \multirow{2}{*}{$\begin{array}{c}F \\
5.045\end{array}$} & \multirow{2}{*}{$\frac{p}{.030}$} & \multirow{2}{*}{$\begin{array}{l}\text { Anlamlı Fark } \\
\text { Lisans-Ön } \\
\text { Lisans }\end{array}$} \\
\hline \multirow{3}{*}{$\begin{array}{l}n \\
\frac{n}{10} \\
\frac{1}{1} \\
\frac{10}{0} \\
\frac{0}{1}\end{array}$} & Yaş & & & & & & \\
\hline & Kıdem & 1.045 & 1 & 1.045 & 3.157 & .083 & $\begin{array}{l}\text { Yüksek } \\
\text { Lisans-Ön } \\
\text { Lisans }\end{array}$ \\
\hline & $\begin{array}{l}\text { Çalışma } \\
\text { süresi }\end{array}$ & .670 & 1 & .670 & 2.024 & .162 & \\
\hline \multicolumn{2}{|c|}{ Öğrenim düzeyi } & 38.660 & 2 & 19.330 & 58.384 & .000 & \\
\hline \multicolumn{2}{|c|}{ Hata } & 13.906 & 42 & .331 & & & \\
\hline \multicolumn{2}{|c|}{ Toplam } & 636.030 & 48 & & & & \\
\hline
\end{tabular}

${ }^{*} \mathrm{p}<.05$

Tablo 6 incelendiğinde oluşturulan modelin anlamlı çıktığı $(F=30.823, p<0.05)$ sonucuna ulaşılmıştır. Bu durumda yaş değişkeninin işleyişte Esnek ve Rahat Olabilme boyutuna ilişkin oluşturulan modelde anlamlı çıktığı görülmektedir. Bir diğer deyişle, İşleyişte Esnek ve Rahat Olabilme boyutunda katılımcıların öğrenim düzeyindeki farklılaşmada, yaş değişkenin etkisi gözlenmiştir. (Uyarlanmış $\left.R^{2}=\% 76\right)$.. Bu koşullarda lisans mezunu ( $\bar{X}=4.04$, yüksek düzey) katılımcıların ön lisans mezunu ( $\bar{X}=1.78$, çok düşük düzey) katılımcılara ve yüksek lisans mezunu ( $\bar{X}=4.52$, çok yüksek düzey) katılımcıların ön lisans mezunu ( $\bar{X}=1.78$, çok düşük düzey) katılımcılara göre algılarının daha yüksek olduğu söylenebilir.

Tablo 7'de katılımcıların öğrenim düzeylerine göre genel örgütsel zeka düzeyine ilişkin yaş, kıdem ve çalışma süresinin ortak değişken olarak alındığı varyans analizi ve analiz sonucunda bulunan farkın kaynağına yer verilmiştir.

Tablo 7. Katılımcıların Öğrenim Düzeylerine Göre Genel Örgütsel Zekâ Algılarına Illişkin Varyans Analizleri (ANCOVA)

\begin{tabular}{|c|c|c|c|c|c|c|}
\hline $\begin{array}{l}\text { Varyansın } \\
\text { Kaynağı }\end{array}$ & $\begin{array}{c}\text { Kareler } \\
\text { Ortalaması }\end{array}$ & $\mathrm{Sd}$ & $\begin{array}{c}\text { Ortalama } \\
\text { Kareler }\end{array}$ & $\mathrm{F}$ & $p$ & $\begin{array}{l}\text { Anlamlı } \\
\text { Fark }\end{array}$ \\
\hline Yaş & .870 & 1 & .870 & 11.916 & .001 & $\begin{array}{l}\text { Lisans-Ön } \\
\text { lisans }\end{array}$ \\
\hline $\begin{array}{l}\frac{n}{\frac{c}{5}} \\
\frac{2}{2} \\
\frac{1}{0} \\
0 \\
\frac{1}{1}\end{array}$ & .352 & 1 & .352 & 4.828 & .034 & $\begin{array}{l}\text { Yüksek } \\
\text { Lisans-Ön } \\
\text { lisans }\end{array}$ \\
\hline $\begin{array}{l}\text { Çalışma } \\
\text { süresi }\end{array}$ & .061 & 1 & .061 & .836 & .366 & \\
\hline
\end{tabular}




\begin{tabular}{lccccc} 
Öğrenim düzeyi & 3.955 & 2 & 1.977 & 27.094 & .000 \\
Hata & 3.065 & 42 & .073 & & \\
Toplam & 535.129 & 48 & & & \\
\hline${ }^{*} \mathrm{p}<.05$ & & &
\end{tabular}

Tablo 7 incelendiğinde oluşturulan modelin anlamlı çıktığı $(F=17.921, p<0.05)$ sonucuna ulaşılmıştır. Bu durumda yaş ve kıdem değişkenlerinin katılımcıların genel örgütsel zeka algısına ilişkin oluşturulan modelde anlamlı çıktığı görülmektedir. Bir diğer deyişle, katılımcıların genel örgütsel zeka puanları öğrenim düzeyindeki farklılaşma, katılımcıların yaş ve kıdemlerinden etkilenmektedir (Uyarlanmış $R^{2}=\% 64.3$ ). Bu koşullarda lisans mezunu ( $\bar{X}=3.52$, yüksek düzey) katılımcıların ön lisans mezunu ( $\bar{X}=2.78$, düşük düzey) katılımcılara ve yüksek lisans mezunu ( $\bar{X}=3.25$, yüksek düzey) katılımcıların ön lisans mezunu ( $\bar{X}=2.78$, düşük düzey) katılımcılara göre genel örgütsel zeka algılarının daha yüksek olduğu söylenebilir.

Tablo 8'de örgütsel zekânın eylemsel boyutlarına ilişkin katılımcıların görüşleri arasında branşlarına göre fark olup olmadığı sorusunda cevap aranmış ve bulgular aşağıda verilmiştir.

Tablo 8. Katılımcıların Branşlarına Göre Örgütsel Zekâ Algılarına Illişkin Betimsel İstatistikler ve Varyans Analizleri (ANOVA)

\begin{tabular}{|c|c|c|c|c|c|c|c|}
\hline Boyutlar & & $\mathrm{N}$ & $\bar{X}$ & ss & $\mathrm{F}$ & $\mathrm{p}^{*}$ & Anlamlı Fark \\
\hline \multirow{3}{*}{$\begin{array}{l}\text { Değişen Durumlara } \\
\text { Uyum Sağlama I }\end{array}$} & $\begin{array}{l}\text { Okul } \\
\text { Öncesi }\end{array}$ & 5 & 4.04036 & .707313 & \multirow{3}{*}{.504} & \multirow{3}{*}{.608} & \\
\hline & Sinıf & 36 & 3.66260 & .920761 & & & \\
\hline & Alan & 7 & 3.56104 & .597454 & & & \\
\hline \multirow{3}{*}{$\begin{array}{l}\text { Paydaşlarla Etkili } \\
\text { Iletişim }\end{array}$} & $\begin{array}{l}\text { Okul } \\
\text { Öncesi }\end{array}$ & 5 & 4.33674 & .663960 & \multirow{3}{*}{7.644} & \multirow{3}{*}{.001} & $\begin{array}{l}\text { Okul Öncesi-Sınıf } \\
\text { Öğretmeni }\end{array}$ \\
\hline & Sinıf & 36 & 2.75505 & .826715 & & & \\
\hline & Branş & 7 & 3.41836 & 1.325368 & & & \\
\hline \multirow{3}{*}{$\begin{array}{l}\text { Eylemde ve Tepkide } \\
\text { Çabukluk }\end{array}$} & $\begin{array}{l}\text { Okul } \\
\text { Öncesi }\end{array}$ & 5 & 3.06049 & .724344 & \multirow{3}{*}{.749} & \multirow{3}{*}{.479} & \\
\hline & Sinıf & 36 & 3.91329 & 2.028541 & & & \\
\hline & Branş & 7 & 3.22296 & 1.387034 & & & \\
\hline \multirow{3}{*}{$\begin{array}{l}\text { Sezebilme ve } \\
\text { Öngörebilme }\end{array}$} & $\begin{array}{l}\text { Okul } \\
\text { Öncesi }\end{array}$ & 5 & 3.93067 & .672474 & \multirow{3}{*}{4.091} & \multirow{3}{*}{.023} & Okul Öncesi-Alan \\
\hline & Sinıf & 36 & 3.06275 & 1.120702 & & & \\
\hline & Alan & 7 & 2.22093 & .570310 & & & \\
\hline \multirow{3}{*}{$\begin{array}{l}\text { Hayal Gücünü } \\
\text { Kullanabilme ve } \\
\text { Yaratıcılık }\end{array}$} & $\begin{array}{l}\text { Okul } \\
\text { Öncesi }\end{array}$ & 5 & 3.51588 & 1.152159 & \multirow{3}{*}{.049} & \multirow{3}{*}{.952} & \\
\hline & Sinıf & 36 & 3.36986 & .996583 & & & \\
\hline & Alan & 7 & 3.39892 & .755478 & & & \\
\hline \multirow{3}{*}{$\begin{array}{l}\text { Isşleyişte Esnek ve } \\
\text { Rahat Olabilme }\end{array}$} & $\begin{array}{l}\text { Okul } \\
\text { Öncesi }\end{array}$ & 5 & 3.21956 & 1.189040 & \multirow{3}{*}{.254} & \multirow{3}{*}{.777} & \\
\hline & Sinıf & 36 & 3.43193 & 1.226068 & & & \\
\hline & Alan & 7 & 3.70294 & .994723 & & & \\
\hline
\end{tabular}




\begin{tabular}{|c|c|c|c|c|c|c|c|}
\hline Boyutlar & & $\mathrm{N}$ & $\bar{X}$ & SS & $\mathrm{F}$ & $p^{*}$ & Anlamlı Fark \\
\hline \multirow{3}{*}{$\begin{array}{l}\text { Değişen Durumlara } \\
\text { Uyum Sağlama II }\end{array}$} & $\begin{array}{l}\text { Okul } \\
\text { Öncesi }\end{array}$ & 5 & 3.25779 & 1.031093 & \multirow{3}{*}{.709} & \multirow{3}{*}{.497} & \\
\hline & Sinıf & 36 & 3.41142 & 1.264622 & & & \\
\hline & Alan & 7 & 3.95924 & .811911 & & & \\
\hline \multirow{3}{*}{ Toplam } & $\begin{array}{l}\text { Okul } \\
\text { Öncesi }\end{array}$ & 5 & 3.62307 & .522727 & \multirow{3}{*}{1.381} & \multirow{3}{*}{.262} & \\
\hline & Sınıf & 36 & 3.2678 & .4571 & & & \\
\hline & Alan & 7 & 3.2952 & .3268 & & & \\
\hline
\end{tabular}

${ }^{*} \mathrm{p}<.05$

Tablo 8'de görüldüğü gibi öğretmenlerin görev yaptıkları ilkokulda genel örgütsel zekâ düzeylerine ilişkin algılarının, öğretmenlerin branşlarına göre istatistiksel olarak anlamlı bir şekilde farklılaşmadığını göstermektedir. Benzer bir bulgu olarak Turan (2017), katılımcıların örgütsel zekâ düzeyine ilişkin algılarının, branşlarına göre göre farklılaşmadığını belirtmiş̧ir. Ancak örgütsel zekanın eylemsel alt boyutlarından Paydaşlarla Etkili Illetişim ve Sezebilme ve Öngörebilme boyutunda anlamlı fark olduğu sonucuna ulaşılmıştır. Bu farklılığın hangi grup ya da gruplardan kaynaklandığını belirlemek üzere, varyansların homojen olması durumunda kullanılan LSD çoklu karşılaştırma testi yapılmıştır.

Öğretmenlerin branşlarına göre, katılımcılar tarafından genel örgütsel zekanın okul öncesi öğretmenleri tarafından yüksek ( $\bar{X}=3.62)$ ve sınıf öğretmenleri ile alan öğretmenleri ve yöneticiler tarafından orta düzeyde ( $\bar{X}=3.26 ; \bar{X}=3.29)$ algılandığı söylenebilir. Ancak örgütsel zekanın eylemsel boyutlarında yapılan varyans analizi sonuçları, Paydaşlarla Etkili iletişim ile Sezebilme ve Öngörebilme eylemsel boyutlarında branşa göre anlamlı farklılık olduğunu göstermektedir. Paydaşlarla Etkili illetişim alt boyutunda okul öncesi öğretmenlerinin $(\bar{X}=4.33$, çok yüksek düzey), sınıf öğretmenlerine ( $\bar{X}=3.66$, yüksek düzey) göre algıları daha yüksektir. Sezebilme ve Öngörebilme alt boyutunda okul öncesi öğretmenlerinin $(\bar{X}=3.93$, yüksek düzey), alan öğretmenlerine ve yöneticilere ( $\bar{X}=2.22$, düşük düzey) göre algıları daha yüksektir.

Tablo 9'da katılımcıların branşlarına göre örgütsel zekânın sezebilme ve öngörebilme boyutuna ilişkin yaş, kıdem ve çalışma süresinin ortak değişken olarak alındığı varyans analizi ve analiz sonucunda bulunan farkın kaynağına yer verilmiştir.

Tablo 9. Katılımcıların Branşlarına Göre Örgütsel Zekânın Sezebilme ve Öngörebilme Boyutuna ilişskin Varyans Analizleri (ANCOVA)

\begin{tabular}{|c|c|c|c|c|c|c|}
\hline $\begin{array}{l}\text { Varyansın } \\
\text { Kaynağı }\end{array}$ & $\begin{array}{c}\text { Kareler } \\
\text { Ortalaması }\end{array}$ & Sd & $\begin{array}{l}\text { Ortalama } \\
\text { Kareler }\end{array}$ & $F$ & $\mathrm{p}$ & Anlamlı Fark \\
\hline \multirow{3}{*}{ 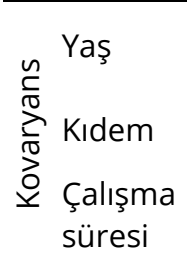 } & 6.764 & 1 & 6.764 & 7.040 & .011 & \multirow[t]{6}{*}{$\begin{array}{l}\text { Okul öncesi- } \\
\text { Alan }\end{array}$} \\
\hline & 5.051 & 1 & 5.051 & 5.257 & .027 & \\
\hline & .203 & 1 & .203 & .211 & .648 & \\
\hline Branş & 7.684 & 2 & 3.842 & 3.999 & .026 & \\
\hline Hata & 40.349 & 42 & .961 & & & \\
\hline Toplam & 497.194 & 48 & & & & \\
\hline
\end{tabular}

${ }^{*} \mathrm{p}<.05$ 
Tablo 9 incelendiğinde oluşturulan modelin anlamlı çıktığı $(F=3.341, p<0.05)$ sonucuna ulaşılmıştır. Bu durumda yaş ve kıdem değişkenlerinin, örgütsel zekânın sezebilme ve öngörebilme boyutuna ilişkin oluşturulan modelde anlamlı çıktığı görülmektedir. Bir diğer deyişle, katılımcıların örgütsel zekânın sezebilme ve öngörebilme boyutuna ilişkin algıları branşlara göre farklılaşmakta ve bu farklılaşmaya yaş ve kıdem değişkenleri etki etmektedir (Uyarlanmış $R^{2}=\% 19.9$ ). Bu koşullarda okul öncesi öğretmenlerinin ( $\bar{X}=3.98$, yüksek düzey), alan öğretmenlerine (rehber öğretmen, Ingilizce öğretmeni, din kültürü ve ahlak bilgisi öğretmeni ve müdür yardımcıları) $(\bar{X}=2.33$, düşük düzey) göre sezebilme ve öngörebilme boyutunda algılarının daha yüksek olduğu söylenebilir.

\section{SONUÇ, TARTIŞMA VE ÖNERILER}

Öğretmen ve yöneticilerin genel örgütsel zeka düzeyine ilişkin algılarının orta düzey olduğu, eylemsel alt boyutlarında ise algılarının yüksek ve orta düzeyde olduğu sonucuna ulaşılmıştır. Öğretmen ve yöneticiler Eylemde ve Tepkide Çabukluk boyutuna ilişkin en yüksek algıya sahipken, Paydaşlarla Etkili İletişim boyutunda bu durum tam tersidir. Okuldaki öğretmen ve yöneticilerin kurumlarının zekâ düzeyine ilişkin algılarının Değişen Durumlara Uyum Sağlama I, Eylemde ve Tepkide Çabukluk, İşleyişte Esnek ve Rahat Olabilme ve Değişen Durumlara Uyum Sağlama II boyutlarında yüksek düzeyde olduğu görülmektedir.

Öğretmen ve yöneticilerin görev yaptıkları ilkokulun genel örgütsel zekâ düzeyine yönelik algılarının, cinsiyetlerine göre istatistiksel olarak anlamlı bir farklılık göstermediği saptanmıştır. Ancak Değişen Durumlara Uyum Sağlama I, Eylemde ve Tepkide Çabukluk ve Sezebilme ve Öngörebilme alt boyunda algılarının istatistiksel olarak anlamlı bir şekilde farklılaşmaktadır. Değişen Durumlara Uyum Sağlama I ve Sezebilme ve Öngörebilme alt boyutlarında, kadın öğretmen ve yöneticilerin erkek öğretmen ve yöneticilere göre daha yüksek bir algıya sahip oldukları belirlenmiştir. Fakat, Eylemde ve Tepkide Çabukluk alt boyutunda, erkek katılımcıların kadın katılımcılara göre daha yüksek bir algıya sahip oldukları ortaya çıkmıştır. Öğretmen ve yöneticilerin görev yaptıkları ilkokulda genel örgütsel zekâ ve eylemsel alt boyutlarına ilişkin algılarının, öğretmenlerin eğitim düzeyine göre istatistiksel olarak anlamlı bir şekilde farklılaştı̆̆ı sonucuna ulaşılmıştır. Buna göre lisans mezunu öğretmen ve yöneticilerin, ön lisans mezunu ve yüksek lisans derecesi sahibi öğretmen ve yöneticilere göre okulun örgütsel zeka düzeyine ilişkin algıları daha yüksektir. Örgütsel zekanın eylemsel alt boyutlarına ilişkin öğretmen ve yönetici algılarında, Paydaşlarla Etkili iletişim ve Eylemde ve Tepkide Çabukluk boyutları dışındaki tüm boyutlarda istatistiksel olarak anlamlı fark tespit edilmiştir. Bir diğer açıdan incelendiğinde, Değişen Durumlara Uyum Sağlama I boyutunda öğretmen ve yöneticilerin öğrenim düzeyindeki farklılaşma, yaş ve kıdem değişkenlerinden etkilenmektedir. Bu koşullarda bulgular yeniden değerlendirildiğinde, ön lisans mezunu öğretmen ve yöneticilerin yüksek lisans mezunlarına ve lisans mezunlarının yüksek lisans mezunlarına göre algılarının Değişen Durumlara Uyum Sağlama I boyutunda daha yüksek olduğu sonucuna ulaşılmıştır. Benzer şekilde, işleyişte Esnek ve Rahat Olabilme boyutunda öğretmen ve yöneticilerin öğrenim düzeyindeki farklılaşmada, yaş değişkenin etkisi olduğu belirlenmiştir. Bulgular yeniden değerlendirildiğinde, lisans mezunu öğretmen ve yöneticilerin, ön lisans mezunlarına ve yüksek lisans mezunlarının ön lisans mezunlarına göre algılarının iş̧leyiş̧te Esnek ve Rahat Olabilme boyutunda daha yüksek olduğu ortaya çıkmaktadır. Ayrıca, genel örgütsel zekaya ilişkin öğrenim düzeyindeki farklılaşma yeniden incelendiğinde, bu farklılaşmanın öğretmen ve yöneticilerin yaş ve kıdemlerinden etkilendiği sonucuna varılmaktadır. Bu durumda lisans mezunu öğretmen ve yöneticilerin ön lisans mezunlarına göre ve yüksek lisans mezunlarının ön lisans mezunlarına göre genel örgütsel zeka algılarının daha yüksek olduğu ortaya çıkmaktadır.Öğretmen ve yöneticilerin genel örgütsel zekâ düzeylerine ilişkin algılarının, branşlarına göre istatistiksel olarak anlamlı bir şekilde farklılaşmadığı, ancak örgütsel zekanın eylemsel alt boyutlarından Paydaşlarla Etkili Illetişim ve Sezebilme ve Öngörebilme boyutunda anlamlı fark olduğu sonucuna ulaşılmıştır. Öğretmenlerin branşlarına göre, genel örgütsel zekanın okul öncesi öğretmenleri tarafından yüksek ve sınıf öğretmenleri ile alan öğretmenleri ve 
yöneticiler tarafından orta düzeyde algılandığı belirlenmiştir. Paydaşlarla Etkili iletişim alt boyutunda okul öncesi öğretmenlerinin sınıf öğretmenlerine göre bu boyuttaki algıları daha yüksektir. Sezebilme ve Öngörebilme alt boyutunda yine okul öncesi öğretmenlerinin, alan öğretmenlerine ve yöneticilere göre algıları daha yüksektir.

Farklı bir analiz ile incelendiğinde, öğretmen ve yöneticilerin örgütsel zekânın sezebilme ve öngörebilme boyutuna ilişkin algıları branşlara göre farklılaşmakta ve bu farklılaşmaya yaş ve kıdem değişkenleri etki etmektedir. Bu açıdan değerlendirildiğinde okul öncesi öğretmenlerinin alan öğretmenlerine (rehber öğretmen, İngilizce öğretmeni, din kültürü ve ahlak bilgisi öğretmeni ve müdür yardımcıları) göre sezebilme ve öngörebilme boyutunda algılarının daha yüksek olduğu sonucuna ulaşılmıştır.Öğretmen ve yöneticilerin algılarına göre genel olarak okullarının orta düzeyde örgütsel zeka düzeyine sahip olduğu ve hızı karar alınması, uyaranların kısa zamanda algılanarak doğru tepki oluşturulması gibi özellikleri içeren Eylemde ve Tepkide Çabukluk boyutunda yüksek algıya sahiptirler. Kadın öğretmen ve yöneticiler ise bu boyutta düşük algıya sahipken, yeni dengelere uygun politika ve stratejilerin geliştirilmesi ve duygusal zekânın örgütsel düzeyde kullanılması özelliklerini içeren Değişen Durumlara Uyum Sağlama I ve Sezebilme ve Öngörebilme boyutunda yüksek algıya sahiptirler. Benzer bir durum öğretmen ve yöneticilerin eğitim durumları için geçerli olup lisans mezunları en yüksek örgütsel zeka algısına sahiptir. Yaş ve kıdem ve çalışma yılı değişkenlerinin etkisi belirlendiğinde lisans ve yüksek lisans mezunu öğretmen ve yöneticiler, ön lisans mezunu öğretmen ve yöneticilere göre örgütün işleyişine ilişkin kuralların gerektiğinde değiştirilebilir nitelikte olması ve bürokratik işlemlerin örgütsel hızı azaltmayacak düzeyde yapılması konularında ilkokulun daha etkili davrandığını düşünmektedirler. Benzer şekilde okul öncesi öğretmenleri Sezebilme ve Öngörebilme boyutunda diğer öğretmen ve yöneticilere göre daha yüksek algıya sahiptir. Bu durum ise kadınların okul öncesi öğretmenliğini tercih etmeleri ve bu çalışmanın cinsiyet değişkenine ilişkin sonuçları ile örtüşmektedir.

Bu çalışma gönüllü katılım koşulu göz önünde bulundurularak örgütsel zekâ kavramının işleyiş açısından oldukça önemli olduğu varsayılan bir birinci kademe eğitim kurumunda gerçekleştirilmiştir. Elde edilen sonuçlar ilkokullardaki örgütsel zekânın ve eylemsel alt boyutlarının farklı değişkenler ile irdelenmesine katkı sağlamaktadır, ancak mevcut araştırmanın benzer veya farklı eğitim kademeleri ile farklı değişkenler göz önünde bulundurularak yapılmasının, sonuçların karşılaştırılabilmesi açısından önemli olduğu düşünülmektedir. Bu durum politika yapıcılar için, farklı özelliklere sahip bireylere hitap eden örgütsel zeka içerikli hizmet içi eğitim uygulamaları için de katkı sağlayacaktır. Başarılı ve etkili okullar için önemli bir faktör olan örgütsel zekanın belirlenmesi ile geliştirilmeye açık boyutların belirlenmesi önemli görülmektedir. Benzer şekilde nitel yöntemler ile desenlenecek farklı çalışmalar, bulguların farklı bir bakış açısı ile değerlendirilmesine olanak sağlayacaktır.

\section{Kaynakça}

Albrecht, K. (2002). Organizational intelligence \& knowledge management: Thinking outside the silos. http//www.karlalbrecht.com adresinden 12.01.2014 tarihinde erişilmiştir.

Barutçugil, i. (2002). Bilgi yönetimi. İstanbul: Kariyer Yayıncılık.

Bümen, N. T. (2005). Okulda çoklu zeka kuramı. Ankara: Pegem A Yayıncılık.

Crossan, M. M., Lane, H. W. ve White, R. E. (1999). An organizational learning framework: From intuition to institution. Academy of Management Review, 24(3), 522-537.

Çakır, R. (2008). Örgütsel zekânın geliştirilmesine ilişkin yapılan bir çalıştayın örgütsel zekô düzeyinin geliştirilmesine etkisi. Yayımlanmamış doktora tezi, Atatürk Üniversitesi, Erzurum.

Erçetin, Ş. Ş. (2001). Örgütsel zeka. Ankara: Nobel Yayın Dağıtım.

Erçetin, Ş.Ş. (2004a). Örgutsel Zekô ve Örgutsel Aptallık. Ankara: Asil Yayın Dağıım. 
Erçetin, Ş.Ş. (2004b). The abilities related to the organizational intelligence and their action dimensions at schools. Res. Educ. Reform, 9(3), 3-18.

Erçetin, Ş.Ş. ve Demirbulak, D. (2002). Action research... organizational Intelligence ... curriculum development. Educational Research Quarterly,26(1), 41-49.

Erçetin, S., Çetin, B. ve Potas, N. (2007). Multi-Dimensional organizational intelligence scale (Muldimorins). World Applied Sciences Journal, 2(3), 151-157.

Erçetin, Ş. Ş., Potas, N., Kisa, N. ve Açikalin, S. N. (2012). To be on the edge of chaos with organizational intelligence and health. Chaos and Complexity Theory for Management: Nonlinear Dynamics: Nonlinear Dynamics, 182-201.

Feuerstein, R. (1990). The theory of structural cognitive modifiability. In Learning and Thinking Styles: Classroom Interaction (Ed. Presseisen, B. Z.). National Education Association School Restructuring Series. NEA Professional Library, West Haven.

Gardner, H. (2006). Multiple Intelligences: New Horizons in Theory and Practice. New York, NY: Basic Books.

Glynn, M. A. (1996). Innovative genius: A framework for relating individual and organizational intelligences to innovation. Academic Management Review, 21(4), 1081-1111.

Halal, W. E. (1998). Organizational intelligence. Knowledge Management Review, 1(2), 45-53.

Huber, G. P. (1991). Organizational learning: The contributing processes and the literatures. Organization Science, 2(1), 88-115.

Istudor, N., Ursacescu, M., Sendroiu, C. ve Radu, I. (2016). Theoretical Framework of Organizational Intelligence: A Managerial Approach to Promote Renewable Energy in Rural Economies. Energies, 9(8), 639.

Kalkan, V. D. (2006). Öncülleri ve sonuçlarıyla işletmelerde örgütsel öğrenme süreci. İ̧̧, Güç Endüstri ilişskileri ve Insan Kaynakları Dergisi, 8(2), 86-103.

Keleş, N. H. ve Özkan, K. T. (2010). Örgütsel zekâ modeli kapsamında çevresel faktörlerin liderlik, strateji ve kuiltüre olan etkisinin incelenmesine yönelik bir araştırma. Journal of Yaşar University, 5(17), 2900-2909.

McGilchrist, I. (2009). The master and his emissary: The divided brain and the making of the western world. New Haven: Yale University Press.

Mills, D. Q. ve Friesen, B. (1992). The learning organization. European Management Journal, 10(2), 146-156.

Minch, R. P. (1990). Hypermedia knowledge management for intelligent organizations. In System Sciences, 1990., Proceedings of the Twenty-Third Annual Hawaii International Conference on (Vol. 4, pp. 300-306). IEEE.

Potas, N., Erçetin, Ş. Ş. ve Koçak, S. (2010). Multi Dimensional Organizational Intelligence Measurements for Determining the Institutional and Managerial Capacity of Girl's Technical Education Institution (Diyarbakır, Şanlıurfa, Konya/Turkey). African Journal of Business Management. 4(8), pp. 1644-1651.

Schwaninger, M. (2003). A cybernetic model to enhance organizational intelligence. Systems Analysis Modelling Simulation, 43(1), 53-65.

Stenvall, J. ve Virtanen, P. (2017). Intelligent public organisations. Public Organization Review, 17(2), 195-209.

Şimşek, M. Ş. ve Çelik, A. (2011). Yönetim ve organizasyon. Konya: Eğitim Kitabevi.

Turan, S. (2017). Okul Yöneticilerinin Kuantum Liderlik Davranışlarının Örgütsel Zekâ Düzeyine Etkisi (Zonguldak ilii Örneği). Yayımlanmamış Doktora Tezi, Hacettepe Üniversitesi, Eğitim Bilimleri Enstitüsü, Ankara. 
Veryard, R. (2016). Building Organizatioal Intelligence, Leanpub.

http://samples.leanpub.com/orgintelligence-sample.pdf adresinden 29.10.2018 tarihinde erişilmiştir.

Walsh, J. P. ve Ungson, G. R. (1991). Organizational memory. Academy of Management Review, 16(1), 57-91.

Yazıcı, S. (2001). Öğrenen organizasyonlar. İstanbul: Alfa Basım Yayım A.Ş.

Yıldırım, E. (2010). Örgütsel öğrenmenin öncülü olarak örgütsel zeka: Teori ve bir uygulama. Sosyal ve Ekonomik Araştırmalar Dergisi, 20, 145-170.

Yildirim, A. ve Şimşek, H. (2005). Sosyal bilimlerde nitel araştırma yöntemleri. Ankara: Seçkin Yayıncılık. 


\section{Extended Summary}

Today's organizations are in intense interaction with the environment with an effort to adapt to changing conditions and situations. In this period of intense change and development, school is one of the main building blocks of the education system, which is shaped by high expectations. It refers to the implementation of all change and development process. In this context, it is expected that the schools that form the basis of the education system should use and develop their organizational intelligence.

This study was carried out in order to determine the effect and importance of the sub-dimensions of organizational intelligence which is an important factor in the ability of producing and using knowledge. In addition, the possibility of comparison between groups on the evaluation of organizational intelligence in terms of variables such as gender, seniority, working time and age are provided. It is important to determine the factors affecting the organizational intelligence and to determine their impact on the process of organizational intelligence.

In this study, which aims to determine the levels of organizational intelligence according to the opinions of school administrators and teachers in a primary school, and to determine whether the organizational intelligence and sub dimensions differ according to the demographic variables, the data were analyzed by using quantitative methods.

The study group consisted of 48 people, who work in a primary school accepted to participate voluntarily to the study, in the Çankaya district of Ankara in the academic year of 2018-2019. Purposive sampling methods were used in the selection of the study group.

In order to determine the level of school intelligence, with the permission of the researchers the "Multidimensional Organizational Intelligence Scale" was used. With this scale, the current situation related to the perceptions of the participants on the organizational dimensions of organizational intelligence and sub dimensions of organizational intelligence were demonstrated. The scale was a 5 point Likert scale and consists of seven dimensions and total 67 items.

The data were analyzed by using descriptive statistics, t-test and variance analysis which are Anova and Ancova.

Based on the findings of this research, the following conclusions can be reached. It was concluded that the perceptions of teachers and administrators about the level of general organizational intelligence were moderate and their perceptions of sub dimension were at high and medium level.

While teachers and administrators have the highest perception in being rapid in action and reaction dimension, this situation is the opposite in terms of Effective Communication with Stakeholders. The perceptions of the teachers and administrators in the school on the level of intelligence are seen to have a high level in Adapting to Changing Situations I, being rapid in action and reaction, being flexible and comfortable and Adapting to Changing Situations II.

It was found that the perceptions of teachers and administrators about the level of general organizational intelligence did not have a statistically significant difference according to their gender. However, the Adaptation to Changing Situations I, being rapid in action and reaction and being intuitive and far-sighted differ significantly in the sub-dimension. In the sub-dimensions of Adapting to Changing Situations I and being intuitive and far-sighted, it was determined that female teachers and administrators had a higher perception than male teachers and administrators. However, it was found that male participants had a higher perception in being rapid in action and reaction sub-dimension than female participants.

It was concluded that the perceptions of the teachers and administrators about the general organizational intelligence and their operational sub-dimensions in the primary school differed statistically according to the education level of the teachers. According to this, teachers and 
administrators who have bachelor's degree have higher perceptions about organizational intelligence level of the school compared to teachers and administrators who have associate's degree and master's degree. A statistically significant difference was found in all dimensions of teacher and manager perceptions regarding the organizational sub-dimensions of Organizational Intelligence except for Effective Communication with Stakeholders and being rapid in action and reaction.

From another statistical perspective, the change in the level of education of teachers and administrators in the being rapid adaptable to changes I dimension is affected by age and seniority variables. When the findings were evaluated in these conditions, it was concluded that the perceptions of the associate degree graduates and the bachelor's degree graduates according to the master's degree graduates were higher in the being rapid adaptable to changes I dimension. Similarly, it has been determined that there is an effect of age variable on teachers' and administrators' level of education at the sub dimension of being flexible and comfortable. When the findings are re-evaluated, it is revealed that the perceptions of the bachelor's degree graduates are higher than master's degree graduates and associate degree graduates, and master's degree graduates are higher than associate degree graduates in the sub dimension of being flexible and comfortable.

When analyzed by a different analysis, perceptions of teachers and administrators regarding the being intuitive and far-sighted dimension of organizational intelligence differ according to branches and this difference is affected by age and seniority variables. When evaluated in this respect, it was concluded that the perception of preschool teachers in terms of being intuitive and far-sighted dimension is higher than the teachers of specific branches. 